\title{
Surface treatment of concrete test specimens subjected to compression
}

\section{Tratamentos superficiais em corpos de prova de concreto submetidos à compressão}
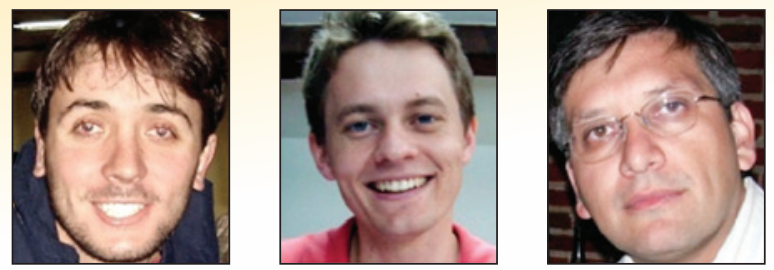

\author{
J. A. CHIES a \\ josuchies@hotmail.com \\ A. B. ROHDEN a \\ abrcivil@gmail.com \\ L. C. P. SILVA FILHO ${ }^{a}$ \\ Icarlos66@gmail.com
}

\begin{abstract}
The technological control of concrete can only be considered a quality control procedure when all its steps are followed properly. Compressive strength testing plays a critical role in the technological control of concrete structures and in the technological development of concrete. The aim of this study is to select the most suitable preparation technique for conventional and high-strength concrete by analyzing mean strength, standard deviation and coefficients of variation. Test specimens with compressive strength ranging from 20 to $120 \mathrm{MPa}$ were prepared in a laboratory and were then subjected to seven different types of surface treatment, using bonded, unbonded and mechanical wear (grinding) systems. Results show that the most effective technique is grinding using a rigid head. The performance of unbonded system was also suitable for use with conventional and high strength concrete.
\end{abstract}

Keywords: surface treatment, test specimens, compressive strength.

\section{Resumo}

O controle tecnológico do concreto só pode ser considerado um procedimento de qualidade, quando todas as suas fases são realizadas adequadamente. O ensaio de resistência à compressão tem importância incontestável no controle tecnológico das estruturas de concreto bem como no desenvolvimento tecnológico do material. O presente trabalho tem como objetivo eleger a técnica de preparação mais adequada para concretos de resistência convencional e de alta resistência através da análise da resistência média, do desvio padrão e do coeficiente de variação. Para isso foram produzidos em laboratório concretos com resistência à compressão de 20 a $120 \mathrm{MPa}$. Estes foram submetidos a sete tratamentos superficiais diferentes, utilizando o sistema aderido, não aderido e por desgaste abrasivo. Como resultado constatou-se que a técnica mais eficiente é o desgaste mecânico por disco rígido. O desempenho do sistema não aderido também foi considerado adequado para concreto convencional e de alta resistência.

Palavras-chave: tratamentos superficiais, corpos de prova, resistência à compressão. 


\section{Introduction}

Item nine of Brazilian standard ABNT NBR 5738 (2003) highlights the importance of the process used to prepare the ends of cylindrical test specimens for axial compressive strength tests. This standard lists three procedures in the preparation: leveling with cement paste, capping and grinding. The standard also list other procedures that can be used as long as the results are first assessed by statistical comparison and are compatible with those obtained in capped test specimens using conventional processes.

To ensure that the compressive strength of concrete samples is determined correctly, it is necessary to ensure an even distribution of the load applied by the bearing blocks on the contact surface of the test specimen. In order to minimize the effect of eccentric loads, ASTM C 39 (2003) determines that the ends of test specimens should be sawed or ground so that they are plane within $0.05 \mathrm{~mm}$. In addition, the ends of test specimens must not depart from perpendicularity to the axis by more than $0.5^{\circ}$. From this perspective, cubic test specimens offer an advantage over cylindrical specimens, as it is easier to obtain at least two parallel surfaces from the six sides of a cube. This aspect is particularly important in high strength concrete as capping, which is the most common method to prepare the ends of test specimens, can break before the concrete (HANSEN et al. 1996).

Most surface treatment techniques fall into three categories: bonded systems (sulfur or cement mortars), unbonded systems (metallic caps with a retained elastomeric pad or wooden plates) and mechanical abrasion systems (grinding with discs or cutting with circular saws), as reported in the literature. Each of these techniques results in different final strengths and for this reason, the most suitable type of treatment for each case should be indicated (TORALLES-CARBONARI, 1996; MINDESS, 1994).

There is consensus in the international literature that the use of sulfur mortar caps in cylindrical test specimens offers good results in concrete with strength below $70 \mathrm{MPa}$. However, when higher strengths are required, mechanical grinding of the ends of the test specimens is recommended (TORALLES-CARBONARI, 1996; DE LARRARD, 1996; HANSEN et al., 1996; AÏTCIN, 1989; PISTILLI; WILLEMS, 1993; BURG; OST, 1992).

In the last five years, several studies in Brazil have discussed this issue, with a particular focus on conventional strength concrete (up to $50 \mathrm{MPa}$ ). However, there is yet no consensus on the subject nor has there been a comprehensive discussion on the effectiveness of the different systems and techniques available for use with high strength concrete.

These studies have compared, for instance, the performance of sulfur mortar caps versus grinding. Most researchers conclude that sulfur mortar caps yield better results (BARBOSA, 2009; RUDUIT, CREMONINI, 2009; BARBOSA, OLIVEIRA, 2010), but some claim that is the preferred choice (ZANETTI, 2009). There are also some studies that suggest that both systems are equally effective (SILVA, et al., 2011.a).

Some comprehensive studies have compared the performance of the three systems available: bonded, unbonded and grinding system. Still, no consensus has emerged on the best technique. Some demonstrate that the use of neoprene caps with a retainer offers best results (JERÔNIMO, et al., 2011) while others claim that the neoprene technique is only recommended for concrete with strengths below $40 \mathrm{MPa}$ and that for higher strengths other systems should be used (MENEZES, CABRAL, 2012). One author proposes that two different systems should be used together, i.e. grinding and the use of neoprene caps with retainers (LOPES, et al., 2012).

This shows that in Brazil, unlike what is observed in other countries, there is yet no consensus on the efficiency of the surface treatment techniques that should be used with cylindrical test specimens of conventional concrete, let alone for high strength concrete.

It should be pointed out that several other aspects related to this issue have been addressed by different studies, such as: test specimen size (VIEIRA, et al., 2008; SILVA, et al., 2010; ARAÚJO, GUIMARÃES e GEYER, 2012); the influence of the degree of saturation of the test specimen (VIEIRA, 2012); the influence of different operators in the final result (GOMES, et al. 2010). In addition, there are also studies in Brazil that make use of construction site data and highlight the importance of preparing the ends of test specimens in a suitable manner (ZANETTI, 2009; SILVA, et al., 2010.a; SILVA, et al., 2010b; LEITÃO, PAMPLONA e CABRAL, 2010; GOMES, et al., 2010; CUNHA e SOARES, 2011; GOMES, LIMA e ASSIS, 2011; SILVA, et al., 2011.b).

\subsection{Justification}

This study aims to analyze the suitability of different systems and the corresponding techniques used to prepare the ends of test specimens according to their respective compressive strength values, given that there is limited awareness of this issue in Brazil.

\section{Materials and experimental program}

\subsection{Materials used}

\subsubsection{Cement}

High initial strength Portland cement (specific mass $=3.11 \mathrm{~kg} / \mathrm{dm}^{3}$ ) was used to cast the test specimens (CPV - ARI). CPV - ARI is the grade with the lowest concentrations of additions (Brazilian standard ABNT NBR 5733, 1991) and the most suitable for the preparation of high strength concrete.

Table 1 shows the chemical composition of the cement types used, the manufacturer's data and the requirements of the applicable Brazilian standard.

Table 2 lists the physical properties of the cement types used, the manufacturer's data and the requirements of the applicable Brazilian standard.

\begin{tabular}{|ccc|}
\hline Table 1-Chemical properties of cement \\
\hline \begin{tabular}{ccc|} 
Properties \\
$(\% \mathrm{~b} / \mathrm{w})$
\end{tabular} & $\begin{array}{c}\text { CP V - ARI } \\
\text { (manufacturer) })\end{array}$ & $\begin{array}{c}\text { Brazilian Standard } \\
\text { ABNT NBR } 5733 / 91 \\
\text { requirements }\end{array}$ \\
\hline $\mathrm{MgO}$ & 3.01 & $\leq 6.50$ \\
$\mathrm{SO}_{3}$ & 4.26 & $\leq 4.50$ \\
Loss on ignition & 3.90 & $\leq 4.50$ \\
\hline
\end{tabular}




\section{Table 2 - Physical properties of the cement used}

\begin{tabular}{|c|c|c|}
\hline Assessed characteristics & CP V - ARI (manufacturer) & $\begin{array}{l}\text { Brazilian Standard ABNT } \\
\text { NBR 5733/91 requirements }\end{array}$ \\
\hline Bulk density $\left(\mathrm{cm}^{3} / \mathrm{g}\right)$ & 3.10 & - \\
\hline Expansion $(\mathrm{mm})$ & 0.0 & $\leq 5.0$ \\
\hline Setting time (h:min) Initial & $02: 55$ & $\geq 01: 00$ \\
\hline Setting time (h:min) Final & 04:35 & $\leq 10: 00$ \\
\hline Consistency (\%) & - & - \\
\hline Blaine fineness $\left(\mathrm{cm}^{2} / \mathrm{g}\right)$ & 4970 & $\geq 3000$ \\
\hline Percentage retained in \#200 $\mu \mathrm{m}$ sieve & 0.16 & $\leq 6.0$ \\
\hline Percentage retained in $\# 3250 \mu \mathrm{m}$ sieve & 1.44 & - \\
\hline
\end{tabular}

\subsubsection{Fine aggregate}

Quartz sand with bulk density $=2.62 \mathrm{~g} / \mathrm{cm}^{3}$ (Brazilian standard ABNT NBR NM 52) and maximum particle size $=4.8 \mathrm{~mm}$ and fineness modulus $=2.4$ (Brazilian standard ABNT NBR NM 248).

\subsubsection{Coarse aggregate}

The coarse aggregate used was crushed basalt with bulk density = $2.90 \mathrm{~g} / \mathrm{cm}^{3}$, (Brazilian standard ABNT NBR NM 53 (2003)), maximum particle size $=25 \mathrm{~mm}$ and shape index 2.66 (Brazilian standards ABNT NBR NM 248 (2003) and ABNT NBR 7809 (1983), respectively).

\subsubsection{Water}

Fresh mains water from the city of Porto Alegre, RS, was used.

\subsubsection{Superplasticizer}

A superplasticizer was used in the compositions with lower water/ binder ratios to produce high strength concrete. A third-generation polycarboxylate based additive with bulk density $=1.087 \mathrm{~g} / \mathrm{cm}^{3}$ and $40 \%$ solids content.

\subsubsection{Silica fume}

Silica fume was only used in high strength concrete mixes. Silica fume has bulk density $=2.20 \mathrm{~kg} / \mathrm{dm}^{3}$, specific surface $20,000 \mathrm{~m}^{2} / \mathrm{kg}$ and average particle size $0.2 \mathrm{~mm}$, according to the manufacturer's data sheet.

\subsection{Methodology}

Concrete compositions were prepared using two different methods. Those mixtures with $\mathrm{w} / \mathrm{b}$ ratios $0.80 ; 0.70 ; 0.60$ and 0.40 were proportioned according to the procedures set in method ACI 211 (1991). Concrete mixes with w/b ratios 0.27 and 0.2 followed the method proposed by Metha and Aïtcin (1990). The proportions and $\mathrm{w} / \mathrm{b}$ ratios are listed in table 3 .

Concrete was mixed in an inclined axis revolving concrete mixer, with a capacity of $250 \mathrm{I}$. Each composition was prepared in a single batch. 35 cylindrical test specimens measuring $10 \mathrm{~cm}$ across and $20 \mathrm{~cm}$ high were molded, following the procedures of Brazilian standard ABNT NBR 5738/03. Before casting the test specimens, slump was determined according to Brazilian standard ABNT NBR NM 67 (1998), and results are shown in table 3.

After casting, test specimens were wrapped in moist burlap bags and stored at room temperature and humidity for 24 hours, when they were removed from the molds and submerged in a tank with saturated lime solution at $23 \pm 2^{\circ} \mathrm{C}$, from where they were removed one day before testing. On the day of the test, the ends of the test specimens received different types of preparation and then had their compressive strength tested.

The surfaces of the test specimens were prepared using three bonded techniques: pure sulfur (AEP), reused sulfur (AER) and sulfur

\section{Table 3 - Mix compositions and w/b ratios}

\begin{tabular}{|c|c|c|c|c|c|c|c|}
\hline \multirow{2}{*}{ Proportion } & \multicolumn{5}{|c|}{ Materials $\mathrm{kg} / \mathrm{m}^{3}$} & \multirow{2}{*}{$\begin{array}{l}w / b \\
\text { ratio }\end{array}$} & \multirow{2}{*}{$\begin{array}{c}\text { Slump } \\
\text { mm }\end{array}$} \\
\hline & Cement & Silica fume & Fine aggregate & Coarse aggregate & Superplasticizer & & \\
\hline 1:3.99:4.92 & 230 & - & 918 & 1131 & - & 0.80 & 100 \\
\hline 1:3.33:4.30 & 263 & - & 8191 & 1131 & - & 0.70 & 170 \\
\hline 1:2.79:3.69 & 307 & - & 854 & 1131 & - & 0.60 & 170 \\
\hline 1:2.18:3.07 & 368 & - & 804 & 1131 & - & 0.50 & 170 \\
\hline 1:1.58:2.45 & 460 & - & 776 & 1131 & - & 0.40 & 120 \\
\hline $1: 0.95 ; 1.23: 2.22$ & 527 & 50 & 650 & 1169 & 5.26 & 0.27 & 140 \\
\hline $1: 0.95: 1.05: 2.07$ & 582 & 56 & 615 & 1205 & 7.00 & 0.20 & 140 \\
\hline
\end{tabular}


prepared according to standard NM 77 (1996) (AEN); two unbonded system techniques: retained neoprene pad with shore hardness 60 (NAN60) and shore hardness 70 (NAN70); and two grinding techniques: rigid wheels (RRDR) and flexible wheels (RRDF). Five test specimens were cast for each type of treatment, resulting in a total of 245 cylindrical test specimens. For each $w / b$ ratio, three cubic test specimens were prepared, for a total of 21 test specimens. These were tested with no surface treatment and were used as a control for comparison with the other treatment methods.

\subsubsection{Mechanical grinding systems}

The mechanical grinding process is outlined in Brazilian standard ABNT NBR 5738 (2003). However, there are different types of equipment that can be used to achieve this. To check whether the differences between different types of equipment and their correct use can affect results, two different grinding devices available in Brazil were used in these tests.

The first is a rigid wheel grinder (RRDR). This device is equipped with a capsule fitted with a mechanical arm that clamps the test specimen in place to ensure the perpendicularity between the diamond grinding wheel and the side of the test specimen. The major advantage of this configuration of this device is that it allows users to set the height of the cutting disk at small intervals. This way, thin layers can be removed per pass until a flat smooth surface is obtained. In order to minimize the effects of vibration, which may affect compressive strength results, the head with the diamond wheel should be advanced slowly and gradually, to remove one layer at a time. Figure 1 shows some of the characteristics of the RRDR device.

The second type of device is a flexible wheel grinder (RRDF), which is the most commonly used equipment. This device is fitted with an angle iron here the test specimen is placed on its side. The operator uses a manual or pneumatic lever to hold the test specimen in place. The basic process for both types of device is the same, i.e. a diamond wheel. One difference is that the clamping system of RRDF grinders is less effective. In addition, this type of equipment does not allow users to adjust the movement of the head or the test specimen with the same degree of precision allowed by RRDR devices. However, the major difference between these devices is the lower rigidity of RRDF grinder, which is directly associated with the planeness defects reported by Ruduit, Cremonini, (2009) and Zanetti (2009). As RRDF grinders are less rigid, the motor produces differential vibration between the grinding disk and the test specimen.

The less rigid the equipment is, the thicker the layer of concrete removed from the test specimen and the lower the rotation of the equipment motor, the stronger the vibration in the assembly.

\subsubsection{Bonded systems}

Bonded systems include a number of different techniques, such as the use of cement paste, epoxy resins and the most traditional method, the use of sulfur. Sulfur poses some health hazards. When heated, it releases toxic $\mathrm{SO} 2$, a powerful irritating agent to the respiratory tract. This gas is hazardous because it combines with water vapor and oxygen in the air to form sulfuric acid inside the lungs (AMORIM et al., 2007; RUDUIT, CREMONINI, 2009; AGUIAR, ARAÚJO e GEYER, 2009; BARBOSA e OLIVEIRA, 2010; LIMA, BASSANI e ALMEIDA JÚNIOR (2010). However, this technique is still used as it is included in a testing standard and it is easy to use, as sulfur builds strength fast and thus increases productivity.

This study used three techniques. The first was the use of sulfur mortar as prescribed by Brazilian Standard ABNT NM 77 (1996). This standard mandates the use of a mixture with $75 \%$ powder sulfur, $20 \%$ inert material (kaolin or filler) and $5 \%$ powder graphite (AEN), at $130^{\circ} \mathrm{C}$ (figure 3 ). At this temperature, the consistency of the sulfur mortar allows for good homogeneity with no precipitation of material at the bottom of the ladle and a suitable viscosity for application.

\section{Figure 1 - Test specimen grinding with RRDR type grinder (B) and rigid diamond wheel (A)}
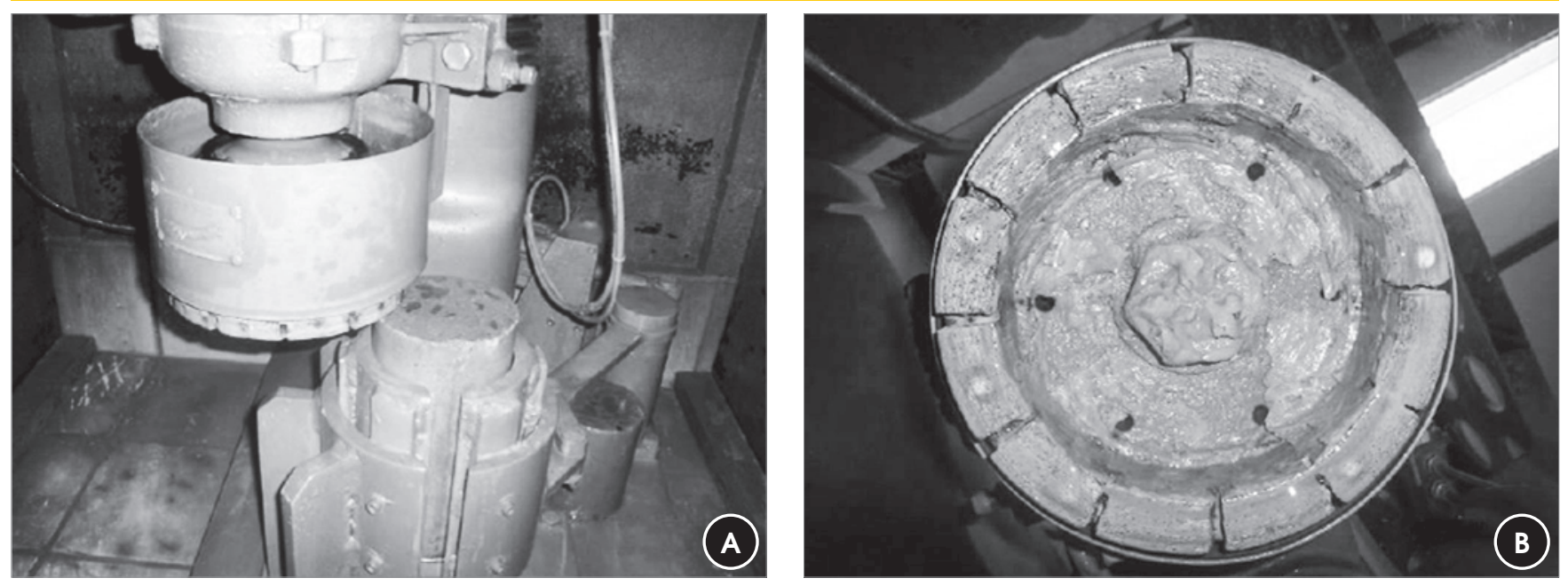
Figure 2 - Test specimen grinding in RRDF grinder (B) and flexible diamond wheel (A)

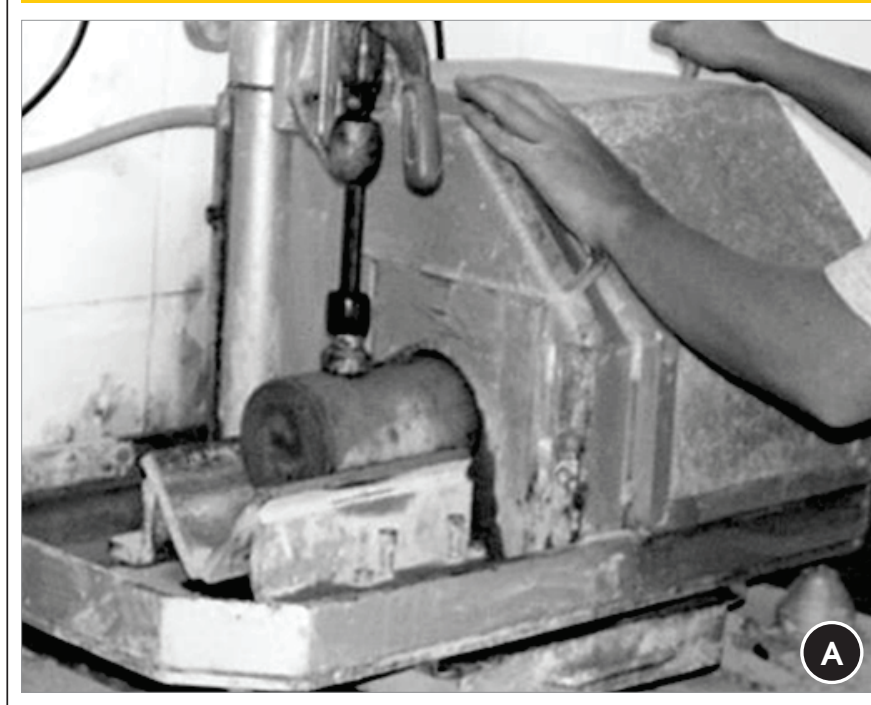

After capping, the test specimens were placed on a clean surface, where they were kept for a minimum of 2 hours for conventional strength concrete and 16 hours for high strength concrete.

The second bonded technique consisted of the use of pure sulfur mortar (AEP). The method followed the same procedure used with $A E N$, with the only difference being the mixture composition, which was prepared only with plain molten sulfur. Pure sulfur was found to be considerably more fluid than the mixture specified in Brazilian Standard ABNT NM 77 (1996).

The third bonded technique was the use of recycled sulfur (AER).

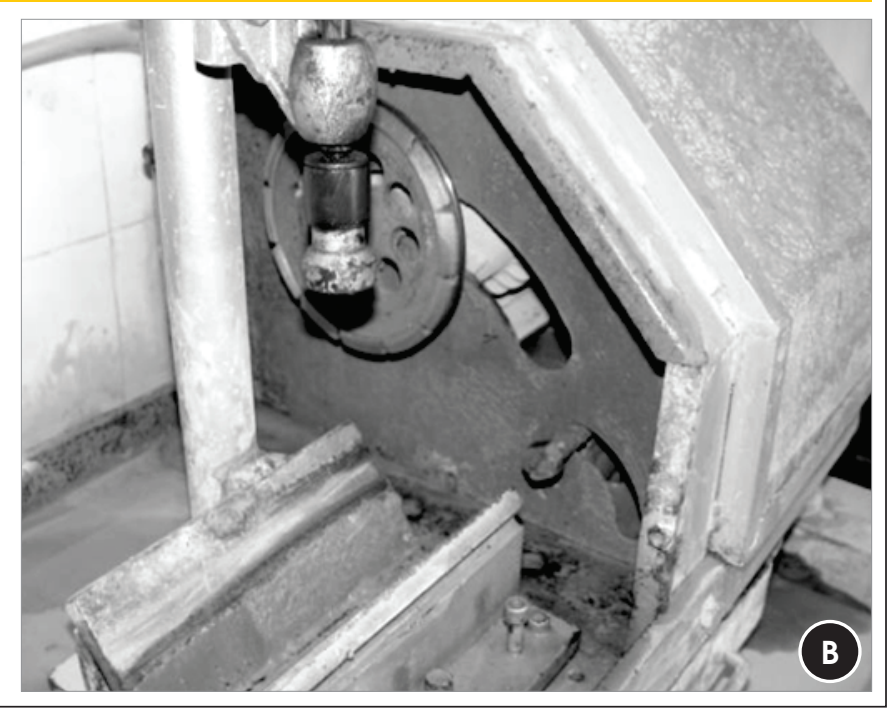

In this method, the sulfur mortar used in test specimens is collected after the samples are tested, and then melted.

\subsubsection{Unbonded systems}

The use of unbonded systems, such as neoprene, has gained increased acceptance in companies and laboratories that work with technological control. ASTM C 1231 (2000) provides guidelines for the test, such as the nominal hardness to be used for each range of compressive strength: pads with Shore hardness 60 (NAN60) are recommended for concrete with strength between 10 and $50 \mathrm{MPa}$,

Figure 3 - Temperature of the sulfur mixture (A) (left) and capping of test specimen (B)
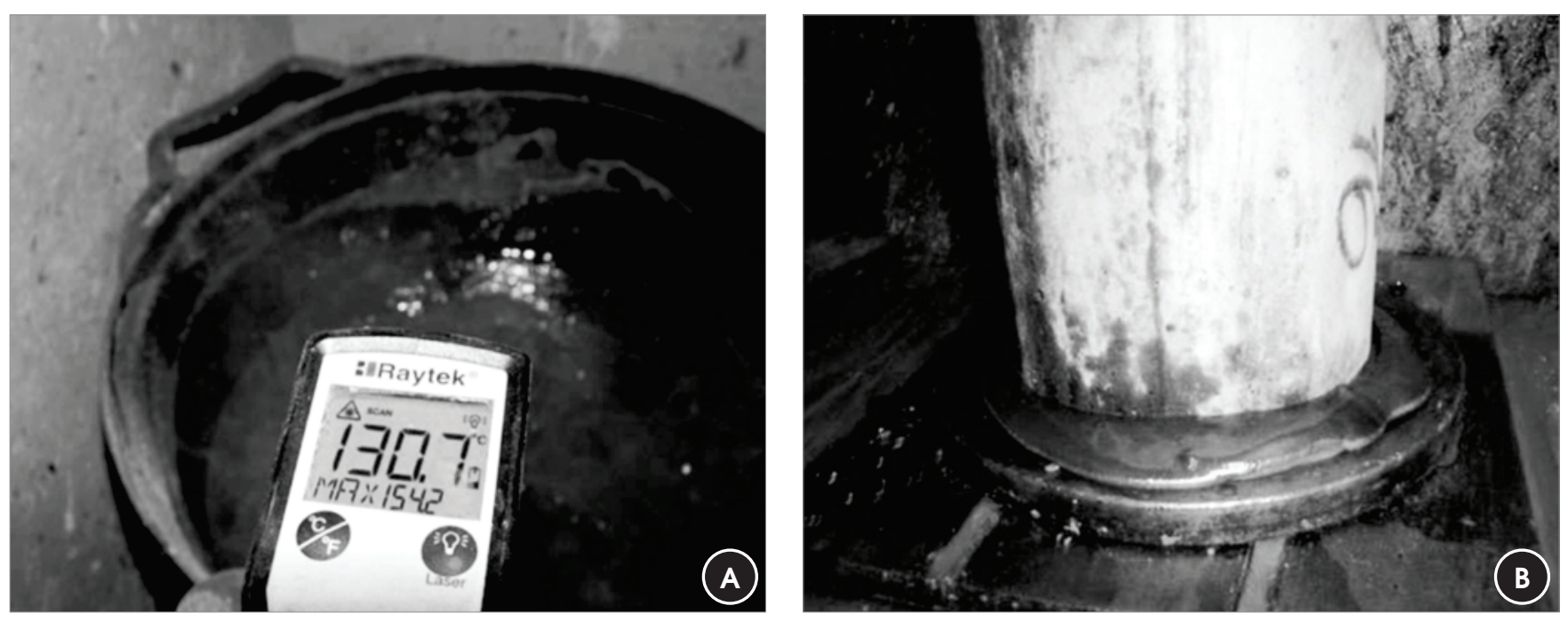


\section{Figure 4 - Neoprene pads with different Shore hardness used in the study}

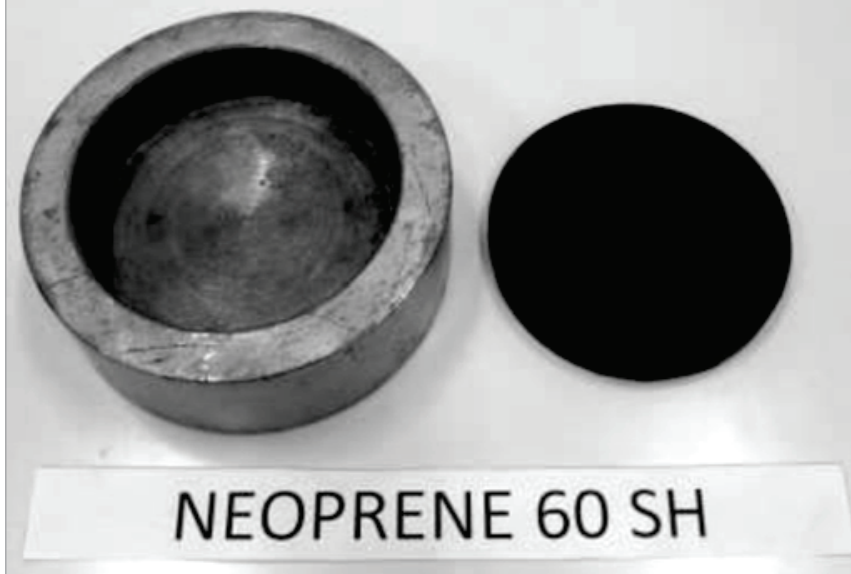

while disks with Shore hardness 70 (NAN70) are used with concrete with strength between 28 and $80 \mathrm{MPa}$.

Neoprene disks measuring $104 \mathrm{~mm}$ across and $10 \mathrm{~mm}$ thick were used. In order to minimize the effect of wear in the disks, each disk was used 5 times only, i.e. a new disk was used with each

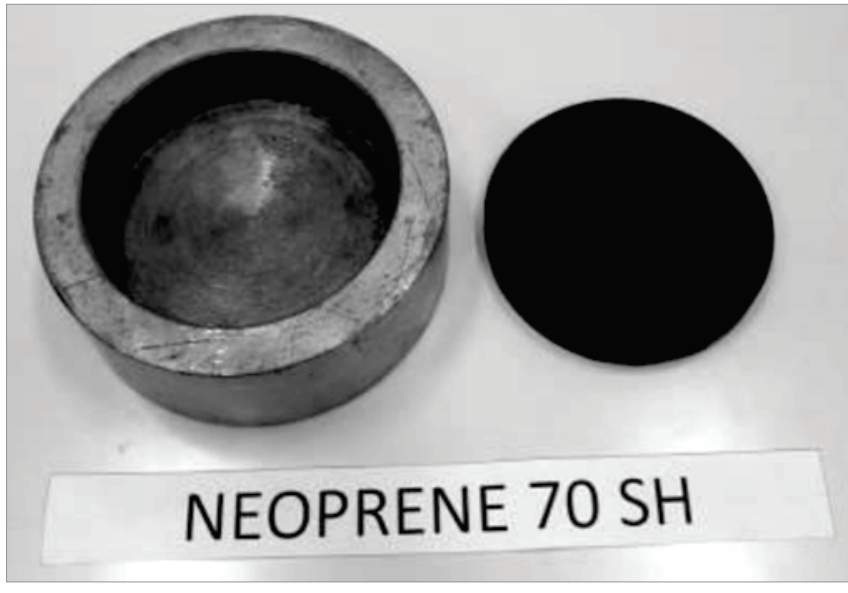

combination. A pair of retaining cups was used to prevent excessive deformation of the neoprene, as figure 4 shows. One pad was used for the bottom end of the test specimen and another for the top end.

In addition to the use of neoprene pads, other unbonded tech-

Table 4 - Individual compressive strength results

\begin{tabular}{|c|c|c|c|c|c|c|c|c|c|c|c|c|c|c|}
\hline \multirow{5}{*}{$\begin{array}{l}\text { Surface } \\
\text { treatiment } \\
\text { AEP }\end{array}$} & \multicolumn{14}{|c|}{ Water/binder ratio } \\
\hline & \multicolumn{2}{|c|}{0.80} & \multicolumn{2}{|c|}{0.70} & \multicolumn{2}{|c|}{0.60} & \multicolumn{2}{|c|}{0.50} & \multicolumn{2}{|c|}{0.40} & \multicolumn{2}{|c|}{0.27} & \multicolumn{2}{|c|}{0.20} \\
\hline & 20.3 & 18.4 & 21.5 & 23.3 & 23.9 & 28.2 & 34.4 & 39.0 & 44.1 & 47.2 & 68.5 & 68.7 & 113.7 & 101.5 \\
\hline & 20.5 & 19.4 & 19.4 & 25.7 & 29.4 & 23.9 & 37.3 & 37.4 & 40.8 & 50.4 & 70.6 & 73.1 & 104.6 & 92.8 \\
\hline & 18.8 & - & 22.5 & - & 30.1 & - & 36.8 & - & 47.4 & - & 74.9 & - & 111.7 & - \\
\hline \multirow{3}{*}{ AER } & 20.3 & 21.1 & 24.4 & 23.3 & 24.9 & 27.8 & 31.0 & - & 40.6 & 42.5 & 51.1 & 49.2 & 54.7 & 42.6 \\
\hline & 19.9 & 18.9 & 23.5 & 21.5 & 26.7 & 27.2 & 33.9 & - & 40.0 & 39.2 & 49.4 & 55.8 & 58.3 & - \\
\hline & 17.4 & - & 23.7 & - & 24.3 & - & - & - & 37.1 & - & 46.4 & - & 45.8 & - \\
\hline \multirow{3}{*}{ AEN } & 19.0 & 21.2 & 23.3 & 25.3 & 25.1 & 27.7 & 35.3 & 39.1 & 50.8 & 45.4 & 77.7 & - & 94.3 & 94.4 \\
\hline & 19.3 & 18.9 & 24.2 & - & 26.0 & 23.8 & 40.0 & 34.5 & 49.4 & 46.0 & 82.3 & - & 104.8 & 83.0 \\
\hline & 19.1 & - & 19.9 & - & 26.7 & - & 34.3 & - & 42.7 & - & 81.9 & - & 91.0 & - \\
\hline \multirow{3}{*}{ NAN60 } & 19.9 & 20.7 & 23.9 & 18.2 & 26.5 & 28.6 & 37.3 & 37.4 & 47.1 & 49.9 & 89.4 & 85.0 & 115.3 & 116.8 \\
\hline & 20.4 & 21.5 & 23.7 & 25.0 & 24.2 & 27.7 & 35.4 & 38.9 & 47.8 & 49.1 & 89.6 & 88.7 & 117.1 & 108.4 \\
\hline & 19.8 & - & 22.6 & - & 28.1 & - & 38.9 & - & 47.3 & - & 91.3 & - & 112.9 & - \\
\hline \multirow{3}{*}{ NAN70 } & 20.6 & 21.0 & 20.6 & 23.6 & 28.3 & 27.4 & 37.0 & 38.0 & 49.7 & 52.0 & 88.4 & 87.3 & 109.8 & 112.9 \\
\hline & 20.4 & 19.9 & 22.0 & 25.6 & 24.6 & 26.3 & 38.7 & 40.0 & 51.6 & 50.3 & 85.7 & 89.7 & 116.6 & - \\
\hline & 21.9 & - & 23.9 & - & 27.2 & - & 38.1 & - & 50.2 & - & 87.1 & - & 106.0 & - \\
\hline \multirow{3}{*}{ RRDR } & 19.9 & 20.2 & 24.3 & 21.4 & 27.8 & 29.0 & 37.1 & 37.1 & 50.1 & 52.2 & 86.5 & 86.8 & 120.3 & 125.8 \\
\hline & 19.9 & 19.6 & 24.5 & 23.8 & 31.1 & 29.8 & 37.3 & 37.9 & 50.1 & 52.7 & 80.3 & 85.3 & 117.1 & 119.7 \\
\hline & 20.7 & - & 24.4 & - & 30.2 & - & 39.3 & - & 50.2 & - & 87.7 & - & 120.3 & - \\
\hline \multirow{3}{*}{ RRDF } & 22.3 & 20.7 & 27.0 & 23.0 & 29.6 & 30.0 & 34.6 & 37.9 & 48.7 & 49.6 & 81.6 & 74.5 & 111.2 & 102.1 \\
\hline & 21.5 & 19.0 & 26.0 & 25.5 & 29.1 & 28.9 & 39.1 & 35.9 & 48.8 & 43.8 & 84.7 & 83.1 & 103.4 & - \\
\hline & 21.4 & - & 26.8 & - & 30.3 & - & 32.0 & - & 43.8 & - & 82.1 & - & 109.4 & - \\
\hline \multirow{3}{*}{ Control } & \multicolumn{2}{|c|}{21.2} & \multicolumn{2}{|c|}{25.6} & \multicolumn{2}{|c|}{32.0} & \multicolumn{2}{|c|}{42.5} & \multicolumn{2}{|c|}{52.9} & \multicolumn{2}{|c|}{88.1} & \multicolumn{2}{|c|}{117.5} \\
\hline & \multirow{2}{*}{\multicolumn{2}{|c|}{$\begin{array}{l}21.0 \\
20.9\end{array}$}} & \multicolumn{2}{|c|}{25.3} & \multicolumn{2}{|c|}{31.1} & \multicolumn{2}{|c|}{40.5} & \multicolumn{2}{|c|}{54.8} & \multicolumn{2}{|c|}{90.4} & & \\
\hline & & & & & & & 41 & & & & 95 & & & \\
\hline
\end{tabular}


Figure 5 - Relative deviation of each single value for the mean value of each combination vs. the compressive strength of each single measurement

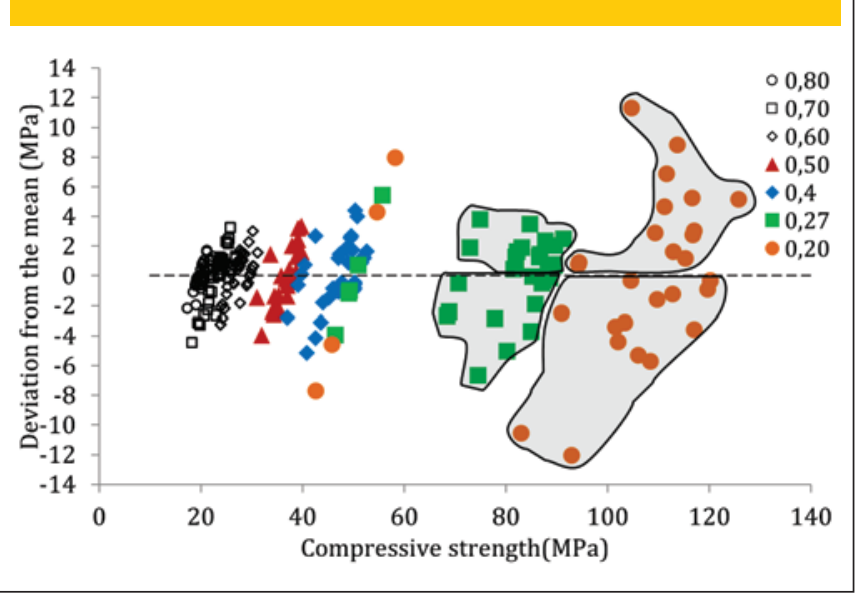

niques are reported in the literature, such as the use of wood plates (AMORIM et al., 2007; LIMA, BASSANI E ALMEIDA JÚNIOR, 2010) and retained sand (LIMA, BASSANI E ALMEIDA JÚNIOR, 2010). Compressive strength tests were performed according to Brazilian Standard ABNT NBR 5739 (1994) in a Shimadzu $2.000 \mathrm{kN}$ press and a stress rate of $0.45 \mathrm{MPa} / \mathrm{s}$, which was kept constant throughout the test.

\section{Results and discussions}

Results were first presented in terms of individual strength values, as shown in table 4 . Absolute deviations were analyzed, and the analysis of variance of the experimental data was shown. Following that, the mean values for compressive strength for each type of surface treatment and for the different concrete compositions were compared. The standard deviations for each strength level and the coefficient of variation were also analyzed.

Figure 5 shows the residual deviation of the individual values in relation to the mean value for each combination. This graph was included as it highlights an important aspect: the range of variation of the deviation values increased proportionally as the concrete strength increased, so higher strength samples show greater disper- sion while conventional strength concrete shows lower dispersion. The error or deviation of the mean is a result of factors that change along the process. Since the same procedure was followed to cast all concrete samples, deviations should be the same. However, as the graph in figure 5 shows, the error or deviation of individual values cannot be assigned to the process only, but should be also understood as being characteristic of the material produced.

Table 5 presented the analysis of variance of the experimental data. This also showed that the two controllable factors (w/b ratio and surface treatment) are significant to the response variable. This indicates that there is a significant difference between the variables under analysis. It is a well-known fact that the first factor, $\mathrm{w} / \mathrm{b}$ ratio, is directly related to concrete strength, and for this reason, a comparison of the mean values for this factor will not be presented. However, for the other controllable factor, surface treatment, which is the main aim of this study, a comparison of the mean values will be made for each $w / b$ ratio value.

\subsection{Comparison of mean values for conventional strength concrete}

Figure 6 shows a comparison of the mean values for the different

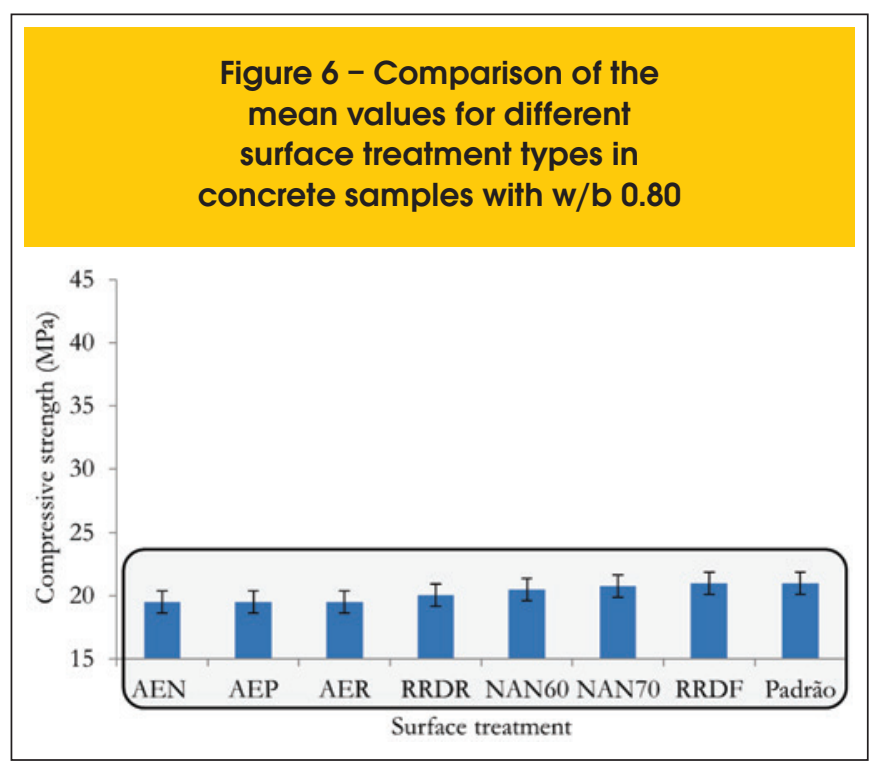

Table 5 - Analysis of variance

\begin{tabular}{ccccccc}
\hline Source & \multicolumn{3}{c}{ Test } & M & Probab & Remarks \\
& SQ & GDL & MQ & F & S \\
A: w/b ratio & 186707.6 & 6 & 31117.94 & 2592.52 & $0,000 \%$ & S \\
B: Surface treatment & 6268.14 & 6 & 1044.69 & 87.04 & $0,000 \%$ & S \\
AB & 13067.94 & 36 & 363.00 & 30.24 & $0,000 \%$ & - \\
Error & 2268.56 & 189 & 12.00 & - & - & - \\
Total & $\mathbf{2 0 8 3 1 2 . 2}$ & $\mathbf{2 3 7}$ & - & - & - & - \\
\hline
\end{tabular}

GDL: degrees of freedom; SQ: sum of squares; $M Q=S Q / G D L:$ mean squares; F: calculated F value: calculated Fisher distribution value; S/N: significant effect (S) and non-significant effect (NS) 


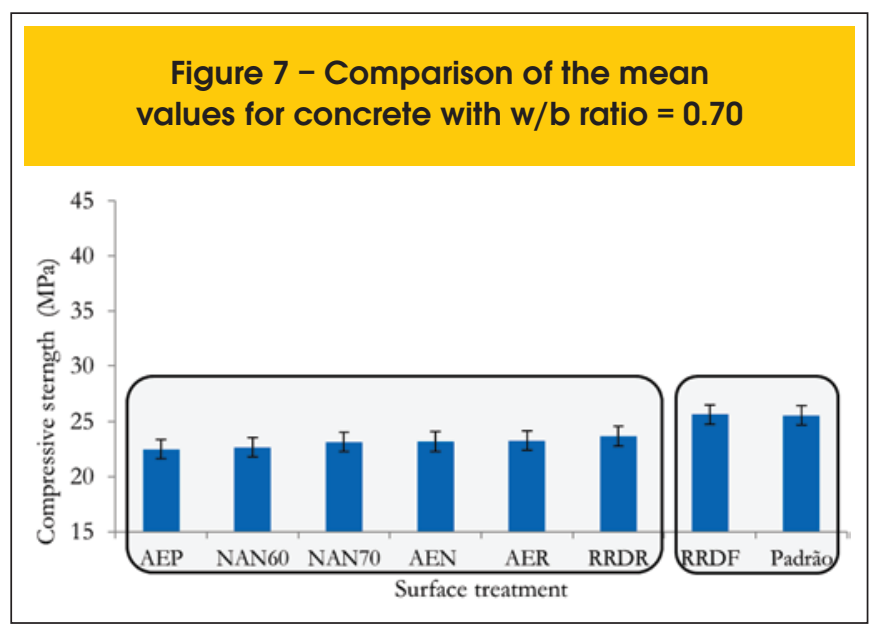

surface treatment systems in concrete mixes with w/b ratio 0.80 . By comparing the means, it is possible to see that the variation found across different systems was not enough for these to be considered statistically different. The decision threshold used in the comparison of the means, obtained from experimental data, is $1.76 \mathrm{MPa}$.

Mean values are compared in order to identify statistically equivalent strength groups. Surface treatment techniques add experimental noise to the measured variable, in this case, mean strength. If we assume that this noise causes mean values to drop, higher mean strength values indicate that a surface treatment is more efficient, as the influence of experimental noise is smaller. For the sake of comparison, the graphs used a cubic test specimen as a control sample, given that it does not have any kind of surface treatment. However, a discussion of the relationship between the strength of cubic and cylindrical test specimens is outside the scope of this study.

Figure 7 shows a comparison of the mean values for the second strength threshold, which corresponds to $\mathrm{a} w / \mathrm{b}$ ratio of 0.70 . For this strength threshold, the flexible wheel grinder showed a compressive strength value that is statistically identical to that of the control sample, but different from the remaining strength values.

Figure 8 shows a comparison of the mean values for the strength threshold corresponding to a $w / b$ ratio of 0.60 . In this case, grind-

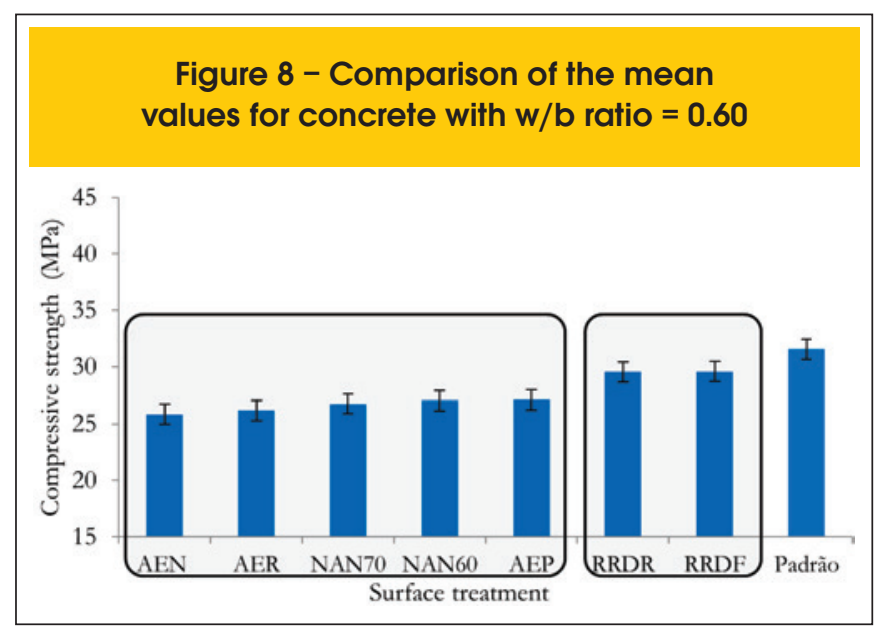

Figure 9 - Comparison of the mean values for concrete with $\mathrm{w} / \mathrm{b}$ ratio $=0.50$

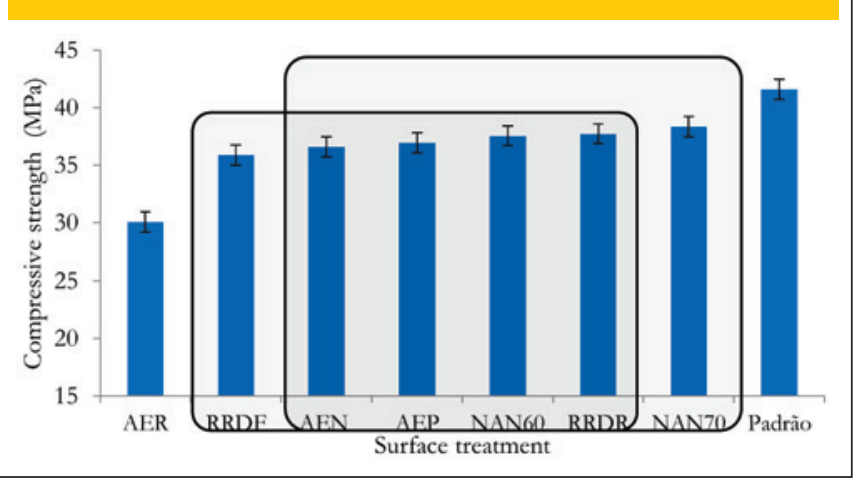

ing techniques display the highest values when statistically compared with the others.

Figure 9 shows a comparison of mean values for the strength level associated with $\mathrm{a} w / \mathrm{b}$ ratio of 0.50 . For this ratio, two groups with statistically equivalent strength levels that are lower than the control can be identified. Only the AER technique showed a significantly lower strength value than these two groups. This translates as a difference of $-10 \mathrm{MPa}$ when compared to the control. This difference is substantial and can be explained by the use of recycled sulfur, which loses the ability to acquire higher strengths after successive reuses.

It should also be highlighted that for conventional strength concrete, the performance of the other techniques was satisfactory in terms of the analysis of mean values. The use of different techniques produces different results for each $w / b$ ratio used. Some are more efficient, other result in higher mean strengths and this accounts for the differences found in the literature about the effectiveness of the methods. However, it is of paramount importance to analyze the deviations corresponding to each of the mean values, because the standard deviation also provides relevant information. A discussion on the deviation is presented in the next section.

Figure 10 - Comparison of the mean values for different surface treatment types and $w / b$ ratio $=0.40$

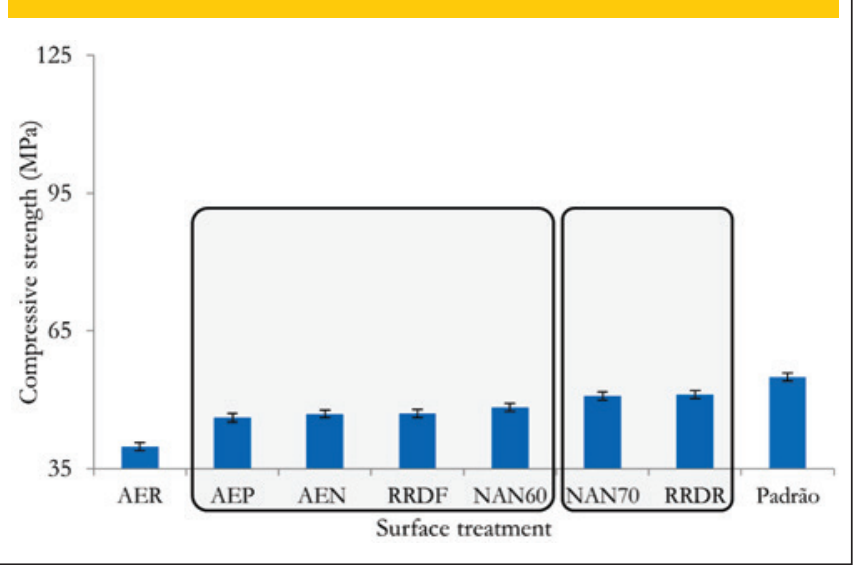




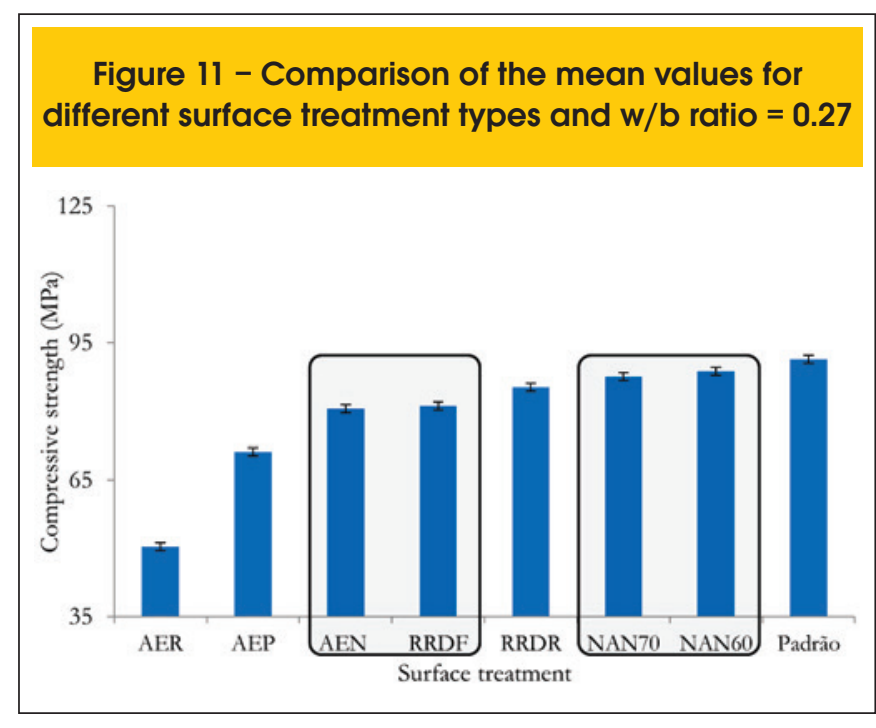

\subsection{Comparison of means for high strength} concrete

Figure 10 shows a comparison of the mean values for concrete mixes with $w / b=0.40$. Two statistically different groups can be identified. The highest strength groups correspond to the RRDR and NAN70 systems.

Figure 11 presents a comparison of mean values for concrete mixes with $\mathrm{w} / \mathrm{b}$ ratio $=0.27$. Unlike what was observed in other mixes, the two unbonded systems in this mix showed statistically higher values than the other systems.

Figure 12 shows a comparison of the mean values for the concrete mixes with $w / b=0.20$. For this strength level, all surface treatment systems show statistically different mean strengths. The RRDR technique stands out as the one with the highest mean strength. Overall, an analysis of the mean values shows that NAN60, NAN70 and RRDR treatments were the most effective. For w/b ratios equal

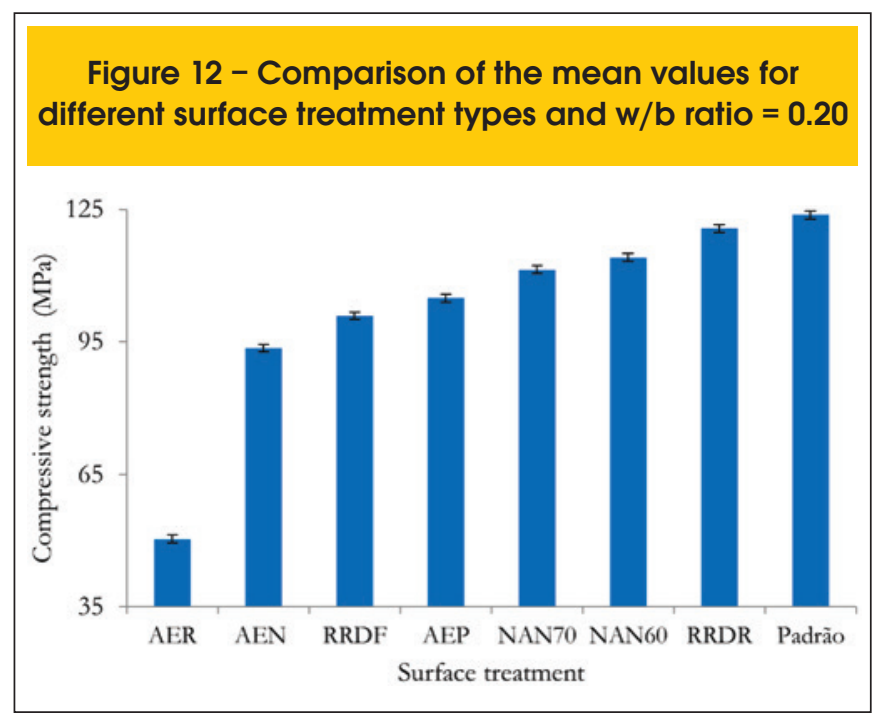

to or below 0.40 , these were the most efficient. It should be remembered that the NAN70 and NAN60 methods were performed with brand new neoprene pads that were used 5 times only. No tests were made on the durability of the pads; therefore, it was not possible to determine how long they would display the same performance.

\subsection{Comparison of standard deviation for each method and of the coefficient of variation}

The standard deviation in the strength of duplicate test specimens is an indication of the reliability of the test. Low standard deviation values indicate low experimental noise.

Figure 13 shows the standard deviation found in bonded systems. The values are higher than those reported by Ruduit and Cremonini (2009) by approximately 1 to $1.5 \mathrm{MPa}$ for conventional concrete, but they are lower than those found by Silva et al (2010).

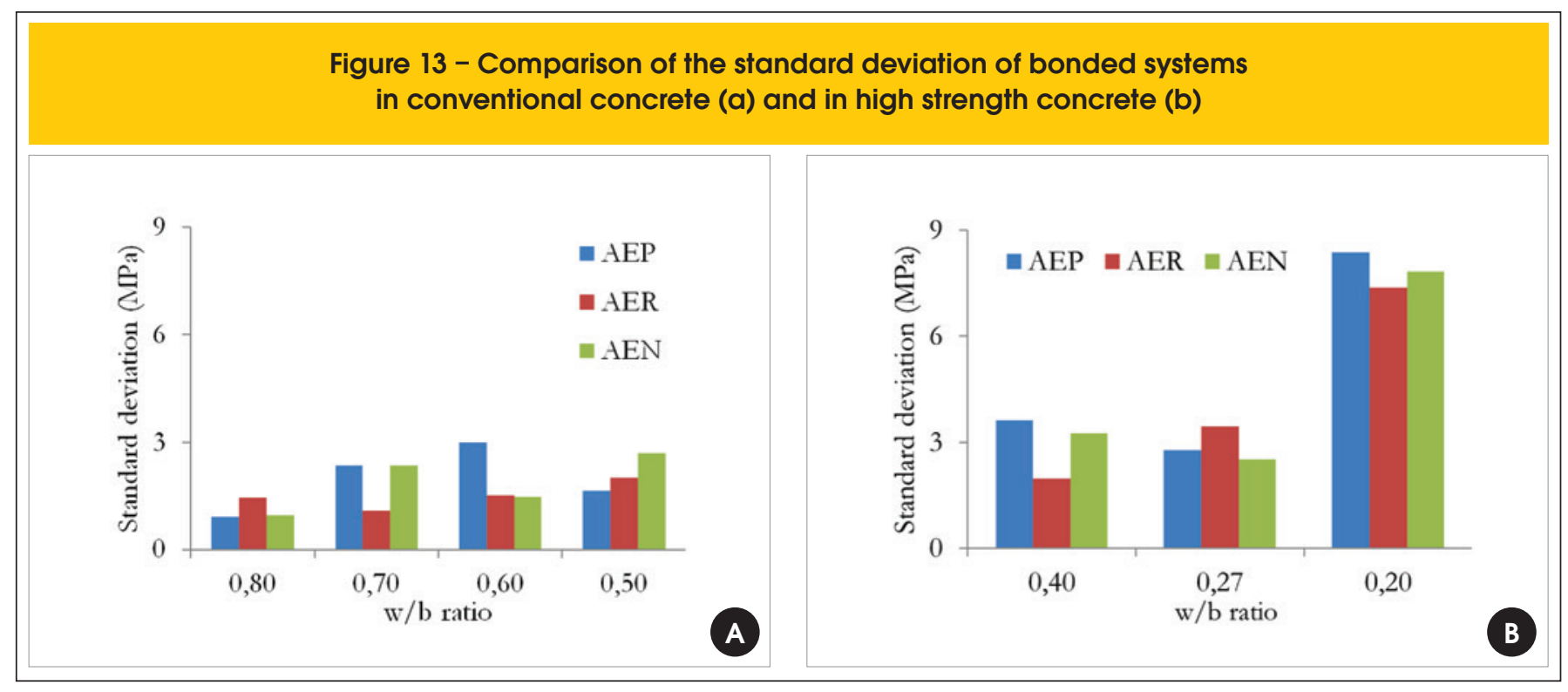


Figure 14 - Comparison of the standard deviation of unbonded systems in conventional concrete (a) and in high strength concrete (b)
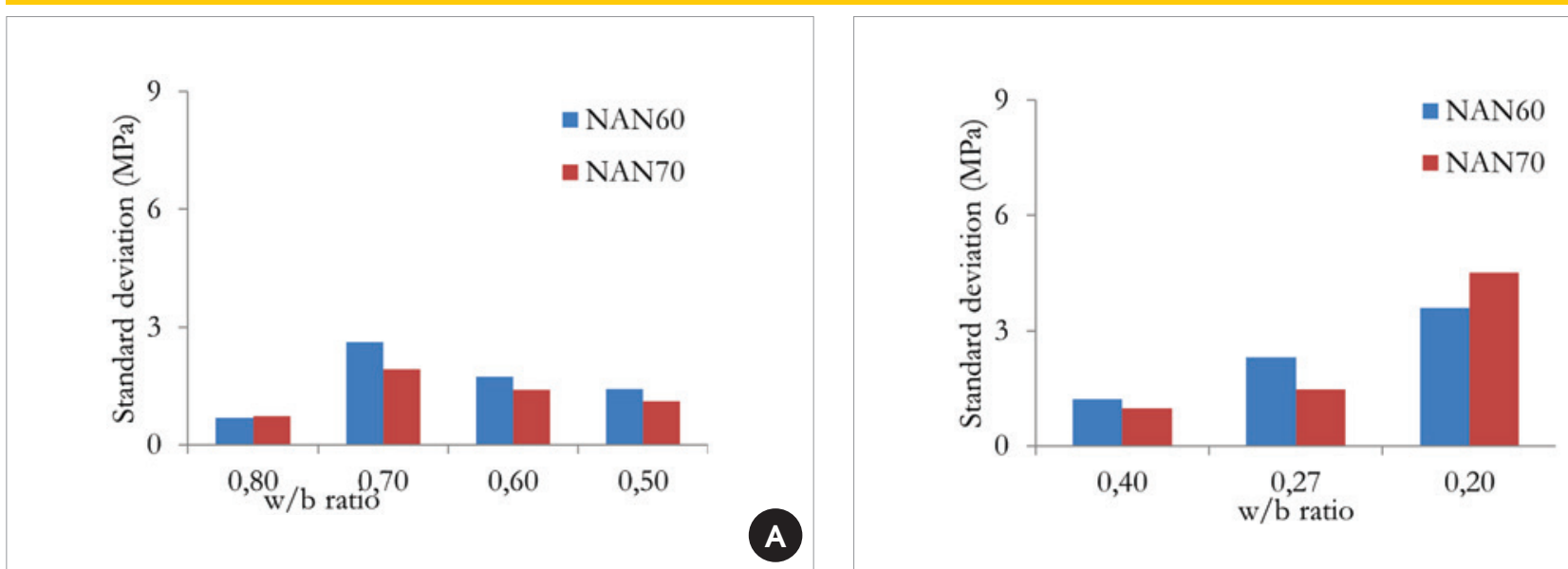

Figure 14 shows the deviation for unbonded systems used with conventional and high strength concrete. The lowest standard deviation values in conventional concrete were recorded with the use of neoprene with Shore hardness 70 . The deviations across the range of $\mathrm{w} / \mathrm{b}$ ratios tested are lower in bonded systems than those observed in unbonded systems. The figures found are of the same order of magnitude as those reported by Lopes et al (2012), who used this technique and obtained standard deviation values between 1.48 and $2.61 \mathrm{MPa}$ for $40 \mathrm{MPa}$ concrete and 4.5 MPa for $60 \mathrm{MPa}$ concrete.

Figure 15 shows the standard deviation values of conventional and high strength concrete when tested with a system of top surface leveling, i.e. mechanical grinding. Only when $w / b=$ 0.6 , the standard deviation of the RDRF technique was lower than the standard deviation of the RDRR technique. The values found are similar to those reported by Ruduit and Cremo- nini (2009) and Silva et al (2012) for the same surface treatment system.

Figure 16 shows a comparison of the most effective technique in each of the three systems. In conventional concrete, the RRDR technique showed the lowest standard deviation. For high strength concrete, the use of NAN70 yielded the lowest standard deviation for concrete mixes with $\mathrm{w} / \mathrm{b}$ ratios of 0.4 and 0.27 .

In addition to standard deviation, another important parameter for analysis is the coefficient of variation. Figure 17 shows the lowest coefficient of variations of each of the three systems for the concrete samples tested. Since the coefficient of variation is the quotient of the standard deviation divided by the mean, it provides a combined analysis of both factors. An analysis of the coefficient of variation shows that, for all the w/b ratios used, the RRDR system results in the lowest value, with the exception of the concrete mixes with $\mathrm{w} / \mathrm{b} 0.4$ and 0.27 .

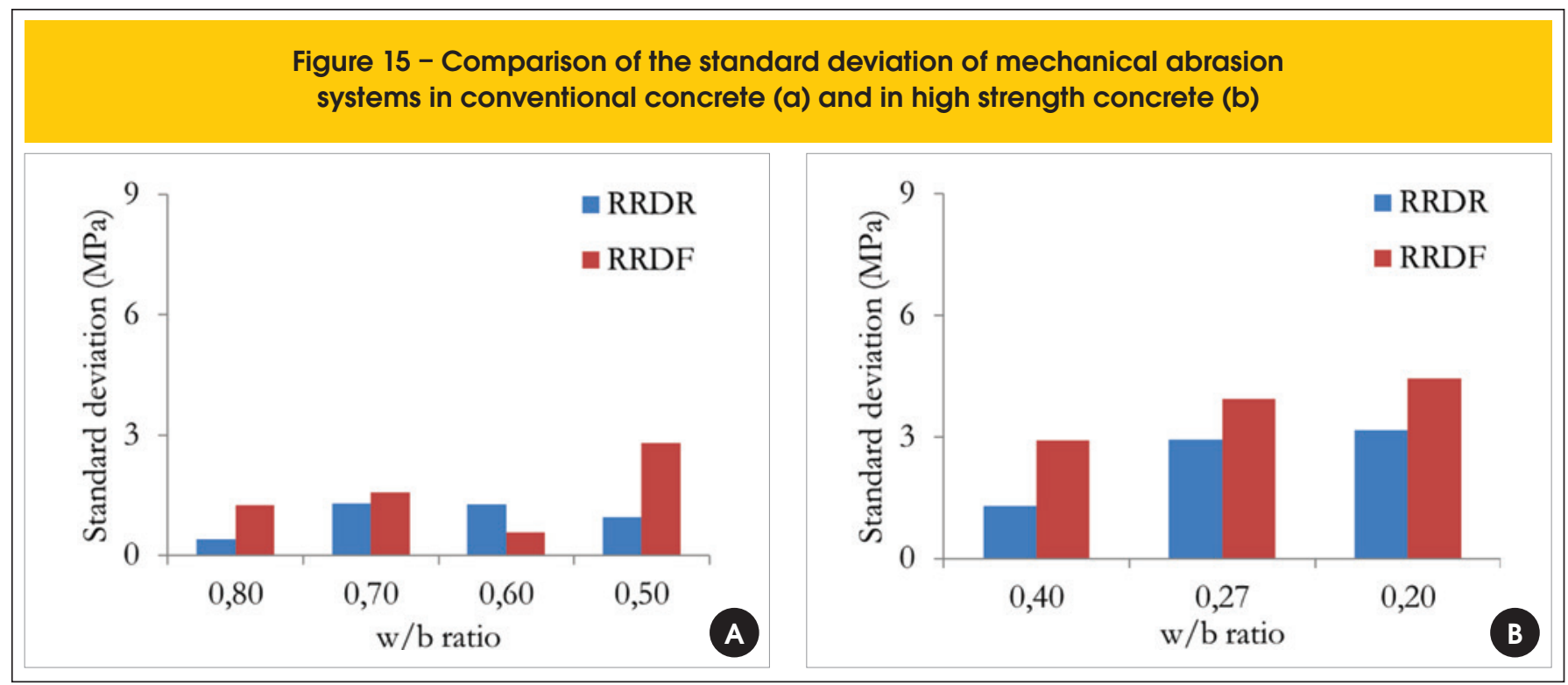




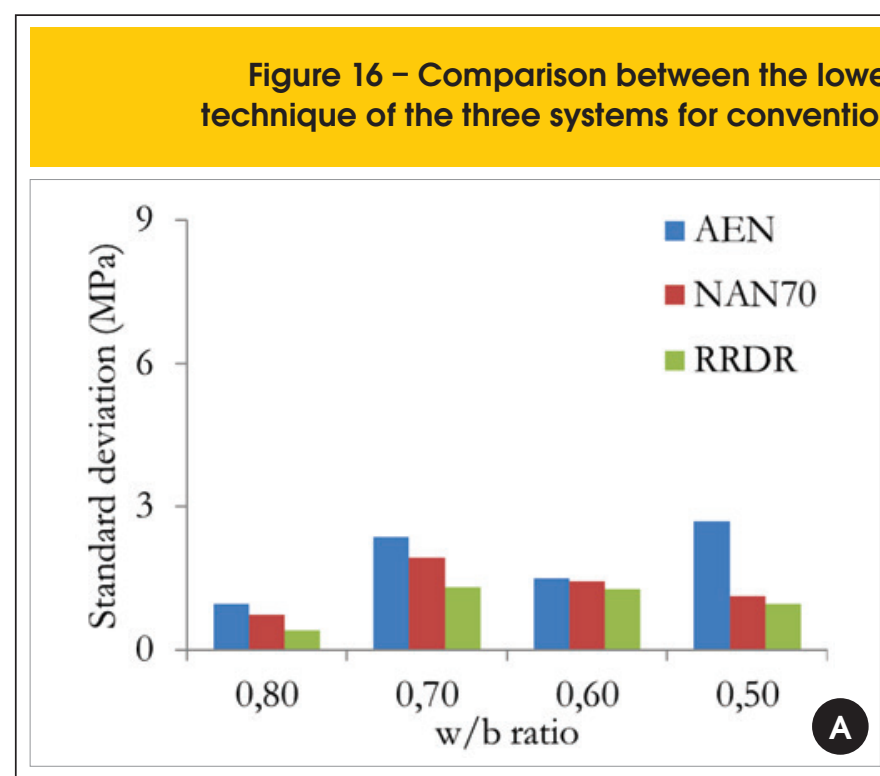

\section{Conclusions}

This study assessed different types of surface treatment for cylindrical test specimens by molding and breaking 245 test specimens. A contribution to the state of knowledge in the area was the inclusions of tests for concrete mixes ranging from $20 \mathrm{MPa}$ to 125 $\mathrm{MPa}$, which had not yet been studied. It was possible to observe that there are significant differences between the systems investigated, as reported in the literature. Another observation is that techniques of the same system can display different results, as is the case of the RRDF and RRDR techniques.

In line with the aims of this study, an analysis of the means shows that the systems investigated have similar results for conventional strength concrete, with the exception of the AER technique. However, when assessing the standard deviation found for groups of five identical test specimens, it was observed that the performance of the RRDR technique was superior to all the other techniques for

Figure 17 - Comparison of the coefficient of variations for the different concrete mixes studied

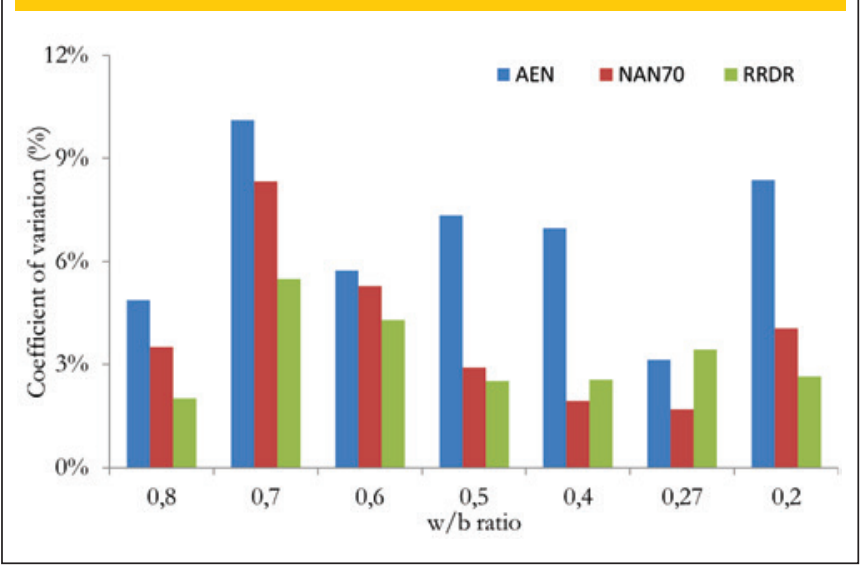

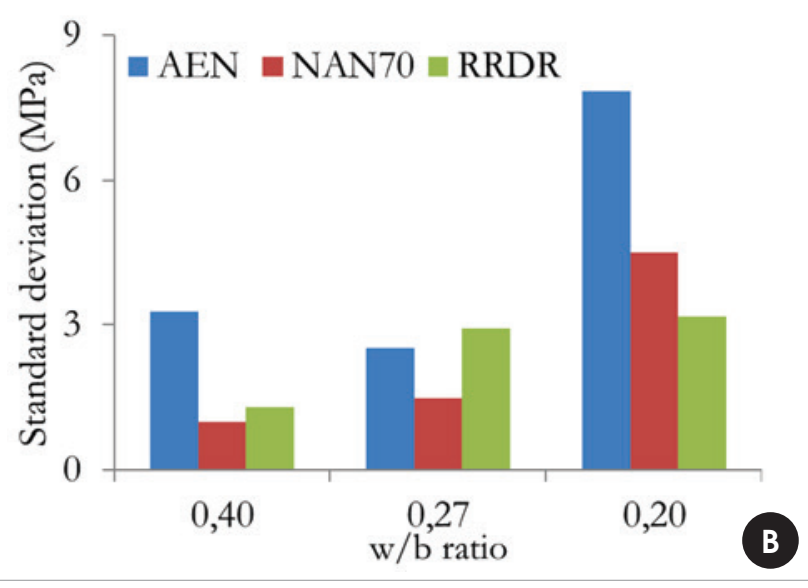

the four $w / b$ ratios used, with the lowest standard deviation values in the test. This was also supported by an analysis of its coefficient of variation, which associates the means with the standard deviation of conventional strength concrete. Thus, it follows that the RRDR technique is recommended for conventional concrete as the most effective one.

For high strength concrete, an analysis of the means shows that the NAN60, NAN70 and RRDR treatments are the most effective, with the three $\mathrm{w} / \mathrm{b}$ ratios below 0.40 being the most effective, i.e. with the highest mean values. The same behavior is observed for standard deviation and coefficient of variation values. The NAN70 technique showed the lowest standard deviation for $w / b$ ratios of 0.40 and 0.27 . The RRDR technique displayed the lowest standard deviation for a $w / b$ ratio of 0.20 . Therefore, the RRDR and the NAN70 techniques are the most suitable for high strength concrete. Future studies may be recommended to investigate the number of tests that can be made using a single neoprene disk while maintaining the same performance obtained in this study.

\section{Acknowledgements}

The authors wish to thank LEME ("Laboratório de Ensaios e Modelos Estruturais") of the Federal University of Rio Grande do Sul (UFRGS) for their support to the testing and to the "Coordenação de Aperfeiçoamento de Pessoal de Nível Superior" (CAPES) for the financial support to this work.

\section{Bibliographic references}

[01] ACl Committee 211.1. Standard practice for selecting proportions for normal, heavyweight, and mass concrete, $\mathrm{ACl}$ Manual of Concrete Practice, Part 1, Concrete Institute, Farmington Hills, MI, 1991.

[02] AGUIAR, R.; ARAÚJO, J.; GEYER, A. Agressão aos trabalhadores e ao meio ambiente de trabalho na utilização do enxofre no capeamento de corpos de prova. $51^{\circ}$ Congresso Brasileiro do Concreto, IBRACON, Curitiba - PR, Outubro, 2009. 
[03] AïTCIN, P. C. (1989). Les betons a très haute resistance. Bulletin Liaison Lab. P. et Ch. Juil-Août, 55-60.

[04] AMERICAN SOCIETY FOR TESTING AND MATERIALS. ASTM C 39 - Standard test method for compressive strength of cylindrical concrete specimens. ASTM Committee C09 on Concrete and concrete Aggregates, 2003.

[05] AMERICAN SOCIETY FOR TESTING AND MATERIALS. ASTM C 1231/C: Standard practice for use of unbounded caps in determination of compressive strength of hardened concrete cylinders. New Mexico, 2000.

[06] Amorim, B.; Sagave, A. M.; Beber, A. J.; Santos, S. Capeamento com enxofre VS. Compensado de madeira: uma alternativa viável. $49^{\circ}$ Congresso Brasileiro do Concreto, IBRACON, Bento Gonçalves - RS, Setembro, 2007.

[07] ARAÚJO, S. S.; GUIMARÃES, G. N.; GEYER, A. L. B. Influência do tipo de concreto, da dimensão do corpo de prova cilíndrico e do tipo de laboratório na determinação da resistência à compressão do concreto. $54^{\circ}$ Congresso Brasileiro do Concreto, IBRACON, Maceió - AL, Outubro, 2012.

[08] ASSOCIAÇÃO BRASILEIRA DE NORMAS TÉCNICAS. NBR NM 52: Agregado miúdo - Determinação da massa específica aparente. Rio de Janeiro: ABNT, 2003.

[09] _. NBR NM 53: Agregado graúdo - Determinação da massa específica, massa específica aparente e absorção de água. Rio de Janeiro: ABNT, 2003.

[10] _. NBR NM 65: Cimento Portland - Determinação dos tempos de pega - método de ensaio. Rio de Janeiro: ABNT, 2002.

[11] _. NBR NM 67: Concreto - Determinação da consistência pelo abatimento do tronco de cone. Rio de Janeiro: ABNT, 1998.

[12] _. NBR NM 77: Concreto - Preparação das bases dos corpos-de-prova e testemunhos cilíndricos para ensaio de compressão. Rio de Janeiro: ABNT, 1996.

[13] _. NBR NM 248: Agregados - Determinação da composição granulométrica. Rio de Janeiro: ABNT, 2003.

[14] _. NBR 5733: Cimento Portland - Cimento Portland de alta resistência inicial - especificação. Rio de Janeiro: ABNT, 1991.

[15] _ _. NBR 5735: Cimento Portland - Cimento Portland de alto-forno - especificação. Rio de Janeiro: ABNT, 1991.

[16] _. NBR 5736: Agregados - Determinação da composição granulométrica. Rio de Janeiro: ABNT, 2003.

[17] _. NBR 5738: Concreto - Procedimento para moldagem e cura de corpos de prova. Rio de Janeiro: ABNT, 2003.

[18] _. NBR 5739: Concreto - Ensaio de compressão de corpos de prova. Rio de Janeiro: ABNT, 1994

[19] _. NBR 7112: Concreto - Execução de concreto dosado em central. Rio de Janeiro: ABNT, 1984.

[20] _. NBR 7809. Agregado Graúdo - Determinação do índice de forma pelo método do paquímetro. Rio de Janeiro, 1983.

[21] _.. NBR 11578: Agregados - Determinação da composição granulométrica. Rio de Janeiro: ABNT, 2003.

[22] BARBOSA, F. R.; MOTA, J. M.; SILVA, A. J. C.; OLIVEIRA, $R$. Análise da influência do capeamento de corpos de prova cilíndricos na resistência à compressão do concreto. $51^{\circ}$ Congresso Brsileiro do Concreto, IBRACON, Curitiba - PR, Outubro, 2009.
[23] BARBOSA, H. A.; OLIVEIRA, S. L. Análise de diferentes tipos de capeamento na resistência à compressão do concreto. $52^{\circ}$ Congresso Brasileiro do Concreto, IBRACON, Fortaleza - CE, Outubro, 2010.

[24] BURG, R. G.; OST, B. W. Engineering properties of commercially available high-strengh concretes, Research and Development Builletin RD104T, Portland Cement Association, 1992.

[25] CUNHA, R. R.; SOARES, L. P. F. Cuidados e precauções nos processos de moldagem, cura e ensaios a compressão axial simples de corpos de prova cilíndricos de concreto usinado como referência a NBR 5738. 53 Congresso Brasileiro do Concreto, IBRACON, Florianópolis - SC, Novembro, 2011.

[26] De LARRARD, F. Mechanical material properties, Proceedings Fourth International Symposium on Utilization of High Strength / High Performance Concrete, 29-31 May, Paris France, 1996. p. 29-38.

[27] GOMES, E. L.; LIMA, F. B.; ASSIS, W. S. Análise estatística da resistência a compressão do concreto produzido em Alagoas de 2004 a $2010.53^{\circ}$ Congresso Brasileiro do Concreto, IBRACON, Florianópolis - SC, Novembro, 2011.

[28] GOMES, E. L.; LIMA, A. L.; SANTOS, R. B.; GOMES, P. C.; ASSIS, W. S. Análise do desempenho de técnicos de laboratório a partir de resultados de resistência à compressão axial de corpos de prova cilíndricos de concreto. $52^{\circ}$ Congresso Brasileiro do Concreto, IBRACON, Curitiba - PR, Outubro, 2010.

[29] HANSEN, E. A., LeIVO, M., RODRIGUES, J.; CATHER, R. Mechanical properties of high strength concrete - Influence of test conditions, specimens and constituents. Proceedings Fourth International Symposium on utilization of high strength/high performance concrete, 29-31 May, Paris France, 1996. p. 187-202.

[30] HELENE, P. L.; TERZIAN, P. R. Manual de dosagem e controle do concreto. Brasília: Pini, 1992.

[31] JERÔNIMO, V. L.; SOUZA, L. A. A. S.; SILVA, B. V.; MARQUES, G. G.; SILVA FILHO, L. C. P. Análise da influência da regularização dos topos de corpos de prova cilíndricos sobre a resistência a compressão do concreto. $53^{\circ}$ Congresso Brasileiro do Concreto, IBRACON, Florianópolis - SC, Novembro, 2011.

[32] LEITÃO, M. T.; PAMPlONA, H.; CABRAL, A. E. B. Estudo do desvio padrão utilizado por usinas de concreto da cidade de Fortaleza. $52^{\circ}$ Congresso Brasileiro do Concreto, IBRACON, Curitiba - PR, Outubro, 2010.

[33] LIMA, M. G.; BASSANI, A. C.; ALMEIDA JÚNIOR, G. S. Estudo de materiais alternativos para capeamento de corpos de prova cilíndricos de concreto para ensaios de resistência a compressão. $52^{\circ}$ Congresso Brasileiro do Concreto, IBRACON, Curitiba - PR, Outubro, 2010.

[34] LOPES, J. B. O.; WILRICH, F. L.; DIAS, C. G.; BERNARDI, $N$. Uso de almofada de neoprene confinada combinada com retificação para ensaios de compressão axial de corpos de prova de concreto. $54^{\circ}$ Congresso Brasileiro do Concreto, IBRACON, Maceió - AL, Outubro, 2012.

[35] MEHTA, P.K; AÏTCIN, P-C. Principles underlying production of high performance concrete. Cement, Concrete \& Aggregates v. 12, n.2, p. 70-78, 1990.

[36] MENEZES, A. J. R.; CABRAL, E. B. Estudo comparativo entre capeamento de corpo de prova de concreto com enxofre, 
uso de neoprene e retificação de topo para ensaio de resistência a compressão axial. $54^{\circ}$ Congresso Brasileiro do Concreto, IBRACON, Maceió - AL, Outubro, 2012.

[37] MINDESS, S. Materials selecction, proportinoning and quality control high performance concrete and applications. Edited by S. P. Shah, P. Sundera, and S. H. Ahmad, 1-25, 1994.

[38] PISTILLI, M. K; WILLEMS, T. Evaluation of cylinder size and capping method in compression strength testing of concrete. Cement, Concrete, and Aggregates, CCAGDP, Vol. 15, No 1 , Summer, 59-69, 1993.

[39] RUDUIT, F. R.; CREMONINI, R. A. Estudo comparativo de métodos de preparo de topos de corpos de prova de concreto para ensaio de resistência a compressão. $51^{\circ}$ Congresso Brasileiro do Concreto, IBRACON, Curitiba - PR, Outubro, 2009.

[40] SILVA, A. J. C.; SANTOS, C. F.; NETO, J. M. C.; MONTEIRO, E. C. B. Discussão dos fatores de influência nas operações de ensaio em corpos de prova de concreto. $52^{\circ}$ Congresso Brasileiro do Concreto, IBRACON, Curitiba - PR, Outubro, 2009. (a)

[41] SILVA, A. S. R.; AZEVEDO, M. T.; COSTA, F. N.; AZEVEDO, A. P.; SANTOS, A. B.; CARMO, A. A. Contribuição para o estudo da influência das dimensões dos corpos de prova cilíndricos na confiabilidade dos resultados de resistência à compressão axial de concretos. $52^{\circ}$ Congresso Brasileiro do Concreto, IBRACON, Curitiba - PR, Outubro, 2010.

[42] SILVA, A. S. R.; AZEVEDO, M. T.; COSTA, F. N.; SANTOS, S. A. B.; BRITO, J. S.; CARMO, A. A. Avaliação dos resultados de resistência a copressão axial de concretos fornecidos a obras em Salvador. $52^{\circ}$ Congresso Brasileiro do Concreto, IBRACON, Curitiba - PR, Outubro, 2010.

[43] SILVA, A. S. R.; AZEVEDO, M. T.; COSTA, F. N.; SILVEIRA, I. P.; CARMO, A. A. Avaliação dos resultados de resistência a compressão axial de concretos fornecidos a obras e produzidos por centrais dosadoras em salvador - parte 2. $53^{\circ}$ Congresso Brasileiro do Concreto, IBRACON, Florianópolis - SC, Novembro, 2011.

[44] SILVA, M. J.; RUBIA, R.; PONCIANO, B.; SANTOS, D. H.; BEZERRA, A. C. S.; PEIXOTO, R. A. F. Influência de dois tipos de capeamento de corpos de prova de concreto. $53^{\circ}$ Congresso Brasileiro do Concreto, IBRACON, Florianópolis - SC, Novembro, 2011.

[45] TORALLES-CARBONARI, B. M. T. Estúdio paramétrico de variables y componentes relativos a la dosificación y producción de hormigones de altas prestaciones, 1996. Universitat Politécnica de Catalunya.

[46] VIEIRA, L. B. P. Análise sobre o impacto da realização do ensaio de compressão axial do concreto na condição saturada contra condição seca. $54^{\circ}$ Congresso Brasileiro do Concreto, IBRACON, Maceió - AL, Outubro, 2012.

[47] VIERA, T. M.; VASCONCELOS, A. S.; LAGO, L. B.; BRANCO, H. L.; SOUZA, P. S. L. Influência da dimensão do corpo de prova de concreto e da forma de capeamento, nos resultados de resistência à compressão e módulo de elasticidade. $50^{\circ}$ Congresso Brasileiro do Concreto, IBRACON, Salvador - BA, Setembro, 2008.

[48] ZANETTI, J. J. Falhas dos processos de laboratório que comprometem a avaliação dos resultados de resistência dos concretos. $51^{\circ}$ Congresso Brasileiro do Concreto, IBRACON, Curitiba - PR, Outubro, 2009. 